\title{
FAKTOR-FAKTOR YANG MEMPENGARUHI MINAT IMPLEMENTASI PSAK NO. 109 PADA ORGANISASI PENGELOLA ZAKAT DI KOTA BALIKPAPAN
}

\author{
Selviyana, Wahyu Junaedi \\ STIE Madani Balikpapan
}

\begin{abstract}
This research aims to examine the influence of attitudes, subjective norms, behavioral control, and knowledge of PSAK No. 109 on the interest in implementing PSAK No. 109 in the Zakat management organization in the city of Balikpapan. Independent variables in this study are attitudes, subjective norms, behavioral control, and knowledge of PSAK No. 109. The number of samples studied was 6 samples from the Zakat management organization in the city of Balikpapan. The research method used is the quantitative research method and the method of analysis used in this study is to use a descriptive analysis with SPSS analysis tool version 20. The results of the hypothesis testing showed that the subjective norms and knowledge of PSAK No. 109 have a significant positive effect on the interest in the implementation of PSAK No. 109. Meanwhile, the attitude and control of behavior has no positive effect on the interest in the implementation of PSAK No. 109 at Zakat Management organization in Balikpapan City
\end{abstract}

Keywords: Theory of Planned Behavior, PSAK No. 109, organization of Zakat

Management

\section{PENDAHULUAN}

Zakat merupakan salah satu dari lima rukun Islam yang merupakan suatu kewajiban yang harus dilaksanakan oleh setiap Muslim yang mampu dan sesuai dengan ketetapan dalam syariat Islam. Posisi sentral zakat dalam ajaran Islam sebagai ritual formal (ibadah mahdah) terpenting, zakat memiliki ketentuan-ketentuan operasional yang lengkap meliputi jenis harta yang terkena zakat (mal al-zakah), tarif zakat (miqdar zakah), batas minimal harta terkena zakat (nishab), batas waktu pelaksanaan zakat (haul) hingga sasaran pembelanjaan zakat (masharif al-zakah) (Wibisono, 2015:1).

Pengelolaan dana zakat sudah seharusnya dikelola dengan baik, karena zakat merupakan bagian dari Ibadah harta yang telah ditentukan tata caranya dalam Islam. Terlebih lagi Indonesia sebagai negara dengan mayoritas penganut agama Islam tentunya memiliki potensi zakat yang besar, maka sudah seharusnya zakat dan 
infaq/sedekah dari para muzakki harus dapat dihimpun, dikelola dan dialokasikan dengan baik. Setiap pengelola zakat dituntut untuk akuntabel dalam pengelolaan zakat untuk menjamin kredibilitas pengelolaan zakat organisasinya di mata masyarakat.

Salah satu upaya untuk menciptakan pengelolaan zakat yang baik dan profesional dilakukan melalui pembentukan organisasi pengelola zakat (OPZ) yang tersebar hampir diseluruh wilayah di Indonesia. OPZ adalah suatu organisasi nirlaba yang bergerak dalam bidang penghimpunan dan penyaluran dana zakat dari muzakki kepada mustahik agar tepat sasaran. OPZ di Indonesia terdiri atas 2 jenis, antara lain Badan Amil Zakat Nasional (BAZNAS) yang merupakan OPZ yang dibentuk oleh Pemerintah, dan Lembaga Amil Zakat (LAZ) yang merupakan OPZ bentukan dari masyarakat sipil dan korporasi. Munculnya banyak OPZ baik milik pemerintah maupun masyarakat diharapkan dapat membantu memaksimalkan penghimpunan dan pengelolaan dana zakat yang ada sehingga tepat guna dan sasaran.

Pemerintah Indonesia mendukung kegiatan pengelolaan dana zakat dan infaq/sedekah oleh organisasi pengelola zakat melalui Undang-Undang No. 23 Tahun 2011 tentang pengelolaan dana zakat. Ikatan Akuntansi Indonesia (IAI) sebagai wadah untuk kegiatan akuntan di Indonesia juga telah menerbitkan Pernyataan Standar Akuntansi Keuangan (PSAK) khusus untuk zakat yaitu PSAK No. 109 Akuntansi Zakat dan Infaq/Sedekah. Tujuan dari diterbitkannya PSAK No. 109 adalah untuk menyamakan bentuk laporan akuntansi untuk seluruh OPZ yang ada ditingkat Pusat, Provinsi maupun Kabupaten/Kota. Laporan keuangan yang disusun oleh OPZ merupakan salah satu bukti bahwa OPZ tersebut mampu melaksanakan implementasi kinerja yang professional dan terpercaya meskipun termasuk ke dalam organisasi nirlaba.

Dengan adanya keseragaman bentuk laporan sesuai dengan ketetapan yang telah ditentukan oleh IAI melalui PSAK No.109 dapat memudahkan proses pengauditan pada OPZ. Laporan keuangan ini juga diharapkan dapat meningkatkan kepercayaan muzakki dan pihak-pihak lain yang terkait kepada OPZ. Namun, meskipun sudah diterbitkan dan disahkan cukup lama penerapan PSAK No. 109 pada OPZ belum berjalan dengan maksimal. Masih banyak OPZ yang belum menjalankan dan menerapkan PSAK No. 109 secara menyeluruh. 
Sangat disayangkan jika penerapan PSAK No. 109 belum dapat dilaksanakan secara maksimal oleh OPZ karena akan berpengaruh pada proses pengauditan laporan keuangan yang disusun oleh organisasi dan akan mempengaruhi kredibilitas OPZ yang dapat menyebabkan turunnya kepercayaan muzakki untuk menyalurkan dana zakat dan infaq/sedekahnya melalui OPZ. Berdasarkan latar belakang dan hasil dari penelitian terdahulu, peneliti akan melakukan penelitian berkaitan dengan minat OPZ dalam mengimplementasikan PSAK No. 109 Akuntansi Zakat.

Dalam Penelitian ini untuk mengukur minat amil dalam mengimplementasikan PSAK No. 109 menggunakan pendekatan Teori Perilaku Terencana yaitu sebuah teori yang merupakan pengembangan dari Teori Tindakan Beralasan yang dirasa kurang tepat karena mengabaikan faktor-faktor sosial yang dalam kehidupan nyata bisa menjadi penentu untuk perilaku individu (Sari Ratna Candra, 2018:298). Di dalam teori perilaku terencana menggunakan tiga konstruk yang mempengaruhi perilaku seseorang yaitu sikap, norma subjektif dan perilaku kontrol.

Berdasarkan uraian diatas maka peneliti akan melakukan penelitian dengan judul "Faktor-Faktor Yang Mempengaruhi Minat Implementasi PSAK No. 109 Pada Organisasi Pengelola Zakat di Kota Balikpapan“. Penelitian ini diambil di Kota Balikpapan dengan melibatkan OPZ baik milik Pemerintah (BAZNAS) maupun OPZ milik perseorangan dan korporasi yang memiliki cabang di Kota Balikpapan dan sudah menerapkan PSAK No. 109 dalam penyusunan laporan keuangannya. Alasan pemilihan OPZ yang sudah mengimplementasikan PSAK No. 109 sebagai objek penelitian, yaitu untuk mengukur faktor-faktor yang mempengaruhi minat OPZ terkait dalam tindakannya menerapkan PSAK No. 109 sebagai basis penyusunan laporan keuangannya. Temuan penelitian ini salah satunya dapat dijadikan masukan bagi OPZ yang belum memiliki minat dalam menerapkan PSAK No. 109 untuk memahami faktor-faktor pendorong dalam menerapkan PSAK No. 109. Adapun rumusan masalah dalam penelitian ini adalah apakah faktor - faktor yang terdiri dari sikap amil, norma subyektif, kontrol perilaku, dan pengetahuan tentang PSAK No. 109 berpengaruh positif terhadap impementasi praktik akuntansi zakat, infaq, dan sedekah sesuai PSAK. No. 109 ? 


\section{KERANGKA TEORI}

\section{Teori Perilaku Terencana}

Akuntansi keperilakuan adalah suatu studi tentang perilaku akuntan atau nonakuntan yang dipengaruhi fungsi-fungsi akuntansi dan pelaporan (Suartana I Wayan, 2010:1). Oleh sebab itu, peneliti akan meneliti kaitan antara perilaku OPZ terhadap minat implementasi PSAK No. 109 yang diteliti dengan menggunakan Teori Perilaku Terencana. Teori Perilaku Terencana atau Theory of Planned Behavior (TPB) merupakan perluasan dari Theory of Reasoned Action (TRA). Ajzen (1991) dalam Sari Ratna Candra (2018:298) mengusulkan Theory of Planned Behavior dengan menambahkan faktor tambahan yang menentukan perilaku individu yaitu kontrol perilaku.

1. Attitude (Sikap) adalah persepsi individu (baik menguntungkan atau tidak menguntungkan) terhadap perilaku tertentu. Sikap terhadap perilaku mempertimbangkan untung atau rugi jika melakukan suatu tindakan dan pertimbangan konsekuensi jika tindakan diambil. Secara umum, semakin individu memiliki penilaian bahwa suatu perilaku akan menghasilkan konsekuensi positif maka individu akan cenderung berniat melakukan perilaku tersebut.

2. Subjective Norm (Norma Subjektif) yaitu penilaian subjektif individu tentang prefensi orang lain dan dukungan untuk berperilaku. Norma subjektif merupakan keyakinan atau penilaian seseorang terhadap bagaimana dan apa yang dipikirkan orang jika suatu tindakan dilakukan dan dorongan bagi seseorang untuk mengikuti apa pendapat orang lain. Norma subjektif tentang suatu perilaku didefinisikan sebagai persepsi individu tentang tekanan sosial untuk melakukan atau tidak melakukan suatu perilaku.

3. Perceived Behavioral Control (Kontrol Perilaku) adalah perasaan seseorang mengenai mudah atau sulitnya mewujudkan suatu perilaku tertentu. Persepsi ini ditentukan oleh keyakinan yang kuat terhadap tersedianya sumber daya dan kesempatan yang dimiliki (control belief strength) yang mendukung atau menghambat perilaku yang akan diprediksi dan besarnya peran sumber daya tersebut dalam mewujudkan perilaku tersebut 
Teori Perilaku Terencana pada penelitian ini digunakan untuk mengungkapkan minat OPZ dalam mengimplementasikan PSAK No. 109 pada penyusunan laporan keuangan OPZ.

\section{Pengetahuan amil tentang PSAK No. 109}

Hutapea dan Thoha (2008) dalam Apriliani Eka (2017) menyatakan bahwa Pengetahuan adalah informasi yang dimiliki seseorang karyawan untuk melaksanakan tugas dan tanggung jawabnya sesuai dengan bidangnya. Pengetahuan merupakan komponen utama kompetensi yang mudah diperoleh dan mudah diidentifikasi. Pengetahuan salah satu hal penting yang harus dimiliki seorang karyawan karena turut menentukan berhasil tidaknya pelaksanaan tugas yang dibebankan kepadanya.

\section{Zakat, Infaq/Sedekah dan Amil}

Zakat dari segi bahasa, zakat memiliki kata dasar " zaka " yang berarti berkah, tumbuh, suci, bersih dan baik. Sedangkan zakat secara terminologi berarti aktivitas memberikan harta tertentu yang diwajibkan Allah SWT dalam jumlah dan perhitungan tertentu untuk diserahkan kepada yang berhak menerima. Zakat dibedakan menjadi dua jenis yaitu zakat fitrah dan zakat maal.

Infaq menurut bahasa adalah membelanjakan, sedangkan menurut terminologi artinya mengeluarkan harta karena taat dan patuh kepada Allah SWT. Infaq terdiri atas dua jenis yaitu infaq wajib dan infaq sunah. Infaq wajib adalah infaq yang jumlah dan bentuknya telah ditentukan misalnya nazar. Sedangkan infaq sunah adalah infaq yang dilakukan seorang muslim untuk mencari ridho Allah SWT.

Sedekah adalah segala pemberian/kegiatan untuk mengharap pahala dari Allah SWT. Dimensi sedekah lebih luas dibandingkan dengan infaq karena sedekah tidak hanya memberikan sesuatu dalam bentuk harta tetapi juga dapat berupa berbuat kebajikan, baik untuk diri sendiri maupun untuk orang lain. Sesuai dengan hadist riwayat HR. Baihaqi berikut yang menyatakan bahwa "Senyuman itu sedekah".

Amil zakat merupakan orang yang bertugas untuk mengurus zakat. Amil mempunyai berbagai macam tugas dan pekerjaan yang berhubungan dengan administrasi dan keuangan zakat Ada beberapa syarat yang harus dipenuhi untuk menjadi seorang amil zakat seperti muslim, mukalaf, jujur, memahami hukum-hukum 
zakat, memiliki kemampuan melaksanakan tugas dan orang yang merdeka bukan budak (Nurhayati Sri \& Wasilah, 2011 : 278-280).

\section{PSAK No. 109 Akuntansi Zakat dan Infaq/Sedekah}

Akuntansi secara umum merupakan suatu sistem informasi yang digunakan untuk mengubah data dari transaksi menjadi informasi keuangan. Proses akuntansi meliputi kegiatan mengidentifikasi, mencatat, dan menafsirkan, mengomunikasikan peristiwa ekonomi dari sebuah organisasi kepada pemakai informasinya (Samryn, 2011:1).

IAI sebagai organisasi akuntan di Indonesia telah membuat standar akuntansi keuangan zakat dan infaq/sedekah. Standar tersebut dimuat dalam PSAK No. 109 Akuntansi Zakat dan Infaq/Sedekah. PSAK No. 109 dibuat untuk menjadi pedoman entitas amil zakat dan infaq/sedekah dalam membuat laporan keuangan dalam rangka memberikan informasi pengelolaan dana zakat dan infaq/sedekah (Pujianto, 2015).

Ada beberapa jenis laporan keuangan yang wajib dibuat oleh OPZ yaitu laporan posisi keuangan, laporan perubahan dana, laporan perubahan aset kelolaan, laporan arus kas dan catatan atas laporan keuangan. Laporan keuangan yang dibuat amil OPZ memiliki beberapa tujuan diantaranya adalah sebagai berikut:

1. Sebagai informasi atas penghimpunan, pendistribusian, dan pendayagunaan zakat, infaq/sedekah dan dana sosial keagamaan lainnya yang bermanfaat dalam pengambilan keputusan atau dibutuhkan oleh pihak-pihak yang berkepentingan,

2. Sebagai alat pertanggungjawaban (akuntabilitas) dan transparasi pengelolaan keuangan organisasi,

3. Membantu memenuhi kewajiban para pihak pengelola zakat untuk menjadi akuntabel secara publik,

4. Membantu memenuhi kebutuhan para pengguna laporan (muzakki, masyarakat luas) yang mempunyai keterbatasan kewenangan, keterbatasan kemampuan atau sumber daya untuk memperoleh informasi dan oleh sebab itu mereka menyandarkan pada laporan sebagai sumber informasi penting,

5. Membantu para pengelola zakat untuk mendapatkan kepercayaan publik, 
6. Membantu para pengelola zakat untuk menumbuhkan kepuasan publik, khususnya muzakki (Megawati \& Fenny, 2014).

\section{Hipotesis}

Hipotesis adalah jawaban sementara terhadap rumusan masalah penelitian, dimana rumusan masalah penelitian telah dinyatakan dalam bentuk kalimat pertanyaan (Sugiyono, 2016:64). Berdasarkan masalah yang diungkapkan di atas dan dari hasil penelitan terdahulu maka hipotesis untuk penelitian pengaruh sikap, norma subyektif, kontrol perilaku dan pengetahuan amil tentang PSAK No. 109 terhadap minat implementasi PSAK No. 109 pada Organisasi Pengelola Zakat (OPZ) adalah sebagai berikut:

1. Pengaruh Sikap amil terhadap minat implementasi akuntansi zakat PSAK No. 109

Sikap amil merupakan salah satu variabel independen yang mempengaruhi implementasi akuntansi zakat PSAK No. 109 pada OPZ yang ada di Kota Balikpapan. Sikap adalah persepsi individu (baik menguntungkan atau tidak menguntungkan) terhadap perilaku tertentu (Sari Ratna Candra, 2018 : 294). Jika amil memberikan respon positif terhadap adanya PSAK No. 109 sebagai pedoman dalam melaksanakan akuntansi zakat dan infaq/sedekah maka semakin besar minat OPZ yang bertindak sebagai amil untuk mengimplementasikan akuntansi zakat PSAK No. 109 dalam kegiatan organisasinya dan begitu pula sebaliknya.

Hasil dari penelitian Ma'sumah dan Amin (2018) dengan judul "Pengaruh Sikap, Norma Subjektif dan Kontrol Perilaku Persepsian Terhadap Niat Berwirausaha Siswa" membuktikan bahwa sikap berpengaruh positif terhadap niat berwirausaha siswa kelas XII di SMKN 2 Wonosobo. Sehingga semakin baik sikap siswa, semakin tinggi pula niat siswa untuk berwirausaha. Penelitian ini didukung oleh hasil penelitian Hatta, dkk (2017) dengan judul "Perilaku Berbagi Pengetahuan Akuntansi Pada Dosen Akuntansi Kota Bengkulu: Pendekatan Theory of Planned 
Behavior (TPB)" menyatakan bahwa sikap yang dipengaruhi oleh faktor self efficacy, jaringan sosial, dan extrinsic reward berpengaruh positif terhadap perilaku berbagi pengetahuan akuntansi. Hasil kedua penelitian tersebut sesuai dengan teori perilaku terencana yang menyatakan bahwa sikap sebagai penentu pertama minat. Hubungan antara sikap amil terhadap minat implementasi praktik akuntansi zakat dan infaq/sedekah sesuai dengan PSAK No. 109 dihipotesiskan sebagai berikut:

\section{$H_{1}$ :Sikap amil berpengaruh positif terhadap minat implementasi akuntansi zakat PSAK No. 109}

2. Pengaruh Norma subjektif amil terhadap minat implementasi akuntansi zakat PSAK No. 109

Norma subjektif merupakan salah satu variabel independen yang mempengaruhi implementasi akuntansi zakat PSAK No. 109 pada OPZ yang ada di Kota Balikpapan. Norma subjektif merupakan keyakinan atau penilaian seseorang terhadap bagaimana dan apa yang dipikirkan orang jika suatu tindakan dilakukan dan dorongan bagi seseorang untuk mnegikuti apa pendapat orang lain (Sari Ratna Candra, 2018 : 295). Semakin banyak pihak-pihak yang mendukung implementasi PSAK No. 109 pada OPZ , maka semakin besar pula minat OPZ yang bertindak sebagai amil untuk mengimplementasikan akuntansi zakat PSAK No. 109 dalam kegiatan organisasinya dan begitu pula sebaliknya.

Hasil dari penelitian Ma'sumah dan Amin (2018) dengan judul "Pengaruh Sikap, Norma Subjektif dan Kontrol Perilaku Persepsian Terhadap Niat Berwirausaha Siswa" membuktikan bahwa norma subjektif berpengaruh positif terhadap niat berwirausaha siswa kelas XII di SMKN 2 Wonosobo. Sehingga semakin besar dukungan dari norma subjektif, semakin tinggi pula niat siswa untuk berwirausaha. Penelitian ini didukung oleh hasil penelitian Hatta, dkk (2017) dengan judul "Perilaku Berbagi Pengetahuan Akuntansi Pada Dosen Akuntansi Kota Bengkulu: Pendekatan Theory of Planned Behavior (TPB)" menyatakan bahwa norma 
subjektif yang dipengaruhi oleh dukungan organisasi dalam penelitian ini berpengaruh positif terhadap perilaku berbagi pengetahuan akuntansi. Semakin besar dukungan dari organisasi, maka semakin tinggi perilaku berbagi pengetahuan akuntansi. Hasil kedua penelitian tersebut sesuai dengan teori perilaku terencana yang menyatakan norma subjektif penentu kedua minat. Hubungan antara norma subjektif amil terhadap minat implementasi praktik akuntansi zakat dan infaq/sedekah sesuai dengan PSAK No. 109 dihipotesiskan sebagai berikut:

\section{H2: Norma subjektif amil berpengaruh positif terhadap minat implementasi}

\section{akuntansi zakat PSAK No. 109}

3. Pengaruh Kontrol Perilaku amil terhadap minat implementasi akuntansi zakat PSAK No. 109

Kontrol perilaku merupakan salah satu variabel independen yang mempengaruhi implementasi akuntansi zakat PSAK No. 109 pada OPZ yang ada di Kota Balikpapan. Kontrol perilaku adalah perasaan seseorang mengenai mudah atau sulitnya mewujudkan suatu perilaku tertentu . Jika semakin banyak faktor kemudahan atau manfaat yang diperoleh OPZ saat mengimplementasikan akuntansi zakat PSAK No. 109, maka semakin besar pula minat OPZ yang bertindak sebagai amil untuk mengimplementasikan akuntansi zakat PSAK No. 109 dalam kegiatan organisasinya dan jika banyak faktor yang menghambat atau kesulitan dalam penerapan PSAK No. 109 maka minat untuk mengimplementasikan PSAK No. 109 semakin berkurang.

Hasil dari penelitian Ma'sumah dan Amin (2018) dengan judul "Pengaruh Sikap, Norma Subjektif dan Kontrol Perilaku Persepsian Terhadap Niat Berwirausaha Siswa" membuktikan bahwa kontrol perilaku berpengaruh positif terhadap niat berwirausaha siswa kelas XII di SMKN 2 Wonosobo. Sehingga semakin banyak indikator kemudahan untuk memulai bisnis, semakin tinggi pula niat siswa untuk berwirausaha. Penelitian ini didukung oleh hasil penelitian Hatta, dkk (2017) dengan judul "Perilaku Berbagi Pengetahuan Akuntansi Pada Dosen Akuntansi Kota Bengkulu: 
Pendekatan Theory of Planned Behavior (TPB)" menyatakan kontrol perilaku berpengaruh positif terhadap perilaku berbagi pengetahuan akuntansi. Semakin bermanfaat kegiatan berbagi tersebut, maka semakin tinggi perilaku berbagi pengetahuan akuntansi. Hasil kedua penelitian tersebut sesuai dengan teori perilaku terencana yang menyatakan kontrol perilaku sebagai penentu ketiga. Hubungan antara kontrol perilaku amil terhadap minat implementasi praktik akuntansi zakat dan infaq/sedekah sesuai dengan PSAK No. 109 dihipotesiskan sebagai berikut:

H3:Kontrol perilaku amil berpengaruh positif terhadap minat implementasi akuntansi zakat PSAK No. 109

4. Pengaruh Pengetahuan amil tentang PSAK No. 109 terhadap minat implementasi akuntansi zakat PSAK No. 109

Pengetahuan adalah informasi yang dimiliki seseorang karyawan untuk melaksanakan tugas dan tanggung jawabnya sesuai dengan bidangnya. Semakin kompeten dan memiliki pengetahuan tentang akuntansi zakat SDM yang ada di OPZ maka semakin besar pula minat OPZ yang bertindak sebagai amil untuk mengimplementasikan akuntansi zakat PSAK No. 109 dalam kegiatan organisasinya dan jika SDM yang dimiliki tidak memiliki pengetahuan yang cukup mengenai akuntansi zakat dan infak/sedekah PSAK No. 109 , maka semakin kecil minat untuk mengimplementasikan PSAK No. 109 dalam kegiatan organisasi.

Hasil penelitian dari Lohanda (2017) dengan judul "Pengaruh Tingkat Pendidikan, Pemahaman Akuntansi, dan Pelatihan Penyusunan Laporan Keuangan Terhadap Pelaporan Keuangan UMKM Berdasarkan SAK ETAP (Studi kasus pada UMKM Kerajinan Batik di Kecamatan Kraton Yogyakarta)" membuktikan bahwa pemahaman akuntansi yang terdiri atas pengetahuan deklaratif \& prosedural berpengaruh positif terhadap pelaporan keuangan UMKM berdasarkan SAK ETAP . Hasil penelitian Apriliani (2017) menyatakan bahwa "Pengaruh Kompetensi Sumber Daya Manusia, Penerapan Standar Akuntansi Zakat dan Infak/ 
Sedekah (PSAK 109), Pengendalian Intern, Pemanfaatan Teknologi Informasi, dan Employee Engagement Terhadap Kualitas Laporan Keuangan Lembaga Amil Zakat di Kota Semarang" menyatakan bahwa kompetensi sumber daya manusia berpengaruh terhadap positif terhadap kualitas laporan keuangan LAZ Kota Semarang. Hubungan pengetahuan amil tentang PSAK No. 109 dengan minat mengimplementasikan praktik akuntansi zakat dan infaq/sedekah dihipotesiskan sebagai berikut:

H4:Pengetahuan amil tentang PSAK No. 109 berpengaruh positif terhadap minat implementasi akuntansi zakat PSAK No. 109

\section{METODE PENELITIAN}

\section{Jenis Penelitian}

Jenis penelitian ini merupakan penelitian kuantitatif. Penelitian kuantitatif adalah metode penelitian yang berlandaskan pada filsafat positivisme yang digunakan untuk meneliti pada populasi atau sampel tertentu. Pengumpulan data menggunakan kuesioner. Analisis data bersifat kuantitatif/statistik, dengan tujuan menguji hipotesis yang telah ditetapkan (Sugiyono, 2016:8).

\section{Sumber Data}

Data yang digunakan dalam penelitian ini adalah data primer. Data primer adalah data yang diperoleh langsung dari sumbernya. Data primer dalam penelitian ini diperoleh dengan cara menyebarkan kuesioner (angket). Para responden diminta untuk memberikan tanggapan melalui kuesioner (angket) yang diberikan secara langsung terkait sikap, norma subyektif, kontrol perilaku, pengetahuan mengenai PSAK No. 109 dan minat dalam mengimplementasikan PSAK No. 109.

\section{Metode Pengumpulan Data}

Metode pengumpulan data yang dilakukan dalam penelitian ini adalah dengan menggunakan metode kuesioner (angket). Kuesioner merupakan teknik pengumpulan 
data yang dilakukan dengan cara memberi seperangkat pertanyaan atau pernyataan tertulis kepada responden untuk dijawabnya. Kuesioner dapat berupa pertanyaan atau pernyataan tertutup atau terbuka, dapat diberikan kepada responden secara langsung atau dikirim melalui pos, atau internet (Sugiyono, 2016:142). Metode pengumpulan data pada penelitian ini dilakukan dengan mendatangi secara langsung OPZ yang ada di Kota Balikpapan dan memberikan kuesioner yang berisi pertanyaan terstruktur sesuai dengan tema penelitian kepada responden.

\section{Populasi dan Sampel}

Populasi adalah wilayah generalisasi yang terdiri atas obyek atau subyek yang mempunyai kualitas dan karakteristik tertentu yang ditetapkan oleh peneliti untuk dipelajari dan kemudian ditarik kesimpulannya (Sugiyono, 2017:80). Populasi dalam penelitian ini adalah seluruh amil yang bekerja di Organisasi Pengelola Zakat di Kota Balikpapan.

Sampel adalah bagian dari jumlah dan karakteristik yang dimiliki oleh populasi tersebut (Sugiyono, 2016:81). Pemilihan sampel dalam penelitian ini menggunakan metode sampel jenuh, yaitu teknik penentuan sampel bila semua anggota populasi digunakan sebagai sampel. Sampel pada penelitian ini adalah amil yang mempunyai wewenang untuk mengambil keputusan yaitu pimpinan OPZ atau kepala cabang OPZ, bagian keuangan yang bertugas menyusun laporan keuangan OPZ serta bagian fundraising \& penyaluran dana zakat dan infaq/sedekah. Alasannya karena pengimplementasian PSAK No. 109 pada OPZ berada di bawah keputusan kepala cabang dan pihak yang ikut mempengaruhi keputusan kepala cabang dalam mengimplementasikan PSAK No. 109 adalah bagian keuangan karena bagian tersebut yang memiliki tanggung jawab dalam penyusunan dan pelaporan keuangan OPZ, bagian fundraising \& bagian penyaluran juga termasuk di dalam sampel karena bagian tersebut memiliki keterkaitan untuk melaporkan penghimpunan juga penyaluran dana zakat dan infaq/sedekah yang dimiliki OPZ pada bagian keuangan .

\section{Metode Analisis Data}

\section{Uji Validitas}


Menurut Sugiyono (2016:121) instrumen yang valid berarti alat ukur yang digunakan untuk mendapatkan data (mengukur) itu valid. Uji validitas digunakan untuk mengetahui bagaimana suatu kuesioner yang telah digunakan oleh peneliti benar-benar mengukur apa yang seharusnya diukur. Uji validitas ini dapat digunakan untuk menguji kevalidan item-item dari suatu kuesioner. Adapun ketentuan dalam uji validitas ini, yaitu:

a. $\quad r$ hitung $\geq \mathrm{r}$ tabel, artinya pertanyaan atau indikator tersebut dinyatakan valid

b. $\quad \mathrm{r}$ hitung $<\mathrm{r}$ tabel, artinya pertanyaan atau indikator tersebut dinyatakan tidak valid

\section{Uji Reliabilitas}

Menurut Ghozali (2016:47) Reliabilitas adalah alat untuk mengukur suatu kuesioner yang merupakan indikator dari variabel atau konstruk. Uji reliabilitas dapat digunakan dengan menggunakan bantuan aplikasi SPSS yang akan menunjukkan hasil setelah melalui uji statistik Cronbach's Alpha. Suatu konstruk atau variabel dikatakan reliabel jika nilai Alpha > 0,70.

\section{Analisis Deskriptif Variabel Penelitian}

Statistik deskriptif adalah statistik yang digunakan untuk menganalisis data dengan cara mendeskripsikan atau menggambarkan data yang telah terkumpul sebagaimana adanya tanpa bermaksud membuat kesimpulan yang berlaku untuk umum atau generalisasi (Sugiyono, 2016:147). Hal yang ternasuk dalam statistik deskriptif antara lain adalah penyajian data melalui tabel, grafik, diagram lingkaran, pictogram, perhitungan modus, median dan mean.

\section{Uji Asumsi Klasik}

\section{Uji Normalitas}

Uji normalitas bertujuan untuk menguji apakah dalam data, variabel terikat dengan variabel bebas keduanya mempunyai hubungan distribusi normal atau tidak. Ada dua cara untuk mendeteksi apakah residual berdistribusi normal atau tidak, yaitu dengan analisis grafik dan uji statistik (Ghozali, 2013:160) . 


\section{Uji Multikolinearitas}

Uji multikolinearitas adalah untuk menguji apakah model regresi ditemukan adanya korelasi antar variabel independen (bebas). Model regresi yang baik seharusnya tidak terjadi korelasi antara variabel bebas yang digunakan dalam penelitiannya. Pengujian multikolinearitas dalam penelitian ini dilihat dari Tolerance dan Variance Inflation Factor (VIF) jika nilai Tolerance $\geq 0,10$ dan VIF $\leq 10$, maka model penelitian terbebas dari Multikoliniearitas.

\section{Uji Heteroskedastisitas}

Heteroskedastisitas berarti varians (variasi) variabel tidak sama untuk semua pengamatan. Ghozali (2013:139) menyatakan jika variance dari residual satu pengamatan ke pengamatan lain tetap,Pengujian heteroskedastisitas dilakukan dengan metode grafik dan uji glejser.

\section{Analisis Regresi Linier Berganda}

Pengujian hipotesis pada penelitian ini menggunakan analisis regresi linear berganda. Analisis regresi linear berganda adalah hubungan secara linear antara dua atau lebih variabel independen dengan satu variabel dependen yang digunakan untuk memprediksi atau meramalkan suatu nilai variabel dependen berdasarkan variabel independen (Priyatno, 2012:80). Adapun formulasi dari model regresi berganda dalam penelitian ini adalah sebagai berikut:

\section{Koefisien Korelasi (R)}

Analisis korelasi ganda (R) digunakan untuk mengetahui hubungan antara dua atau lebih variabel independen terhadap variabel dependen secara serentak. Nilai R berkisar antara 0 sampai 1 , nilai semakin mendekati 1 berarti hubungan yang terjadi semakin kuat

\section{Koefisien Determinasi $\left(\mathbf{R}^{2}\right)$}


Koefisien determinasi $\left(\mathrm{R}^{2}\right)$ pada intinya mengukur seberapa jauh kemampuan model dalam menerangkan variasi variabel dependen. Nilai koefisien determinasi adalah antara nol dan satu. Nilai $\mathrm{R}^{2}$ yang kecil berarti kemampuan variabel-variabel independen dalam menjelaskan variasi variabel dependen amat terbatas (Ghozali, 2013:97).

\section{Pengujian Hipotesis}

\section{Uji Statistik F}

Uji statistik F pada dasarnya menunjukkan apakah semua variabel independen atau bebas yang dimasukkan dalam model mempunyai pengaruh secara bersama-sama terhadap variabel dependen/terikat (Ghozali, 2013:98). Uji F ini membandingkan nilai Fhitung dengan nilai $\mathrm{F}_{\text {tabel }}$ pda tingkat keyakinan tertentu untuk melihat tingkat signifikan pengaruh variabel bebas terhadap variabel terikat.

\section{Uji Signifikansi/Uji Parsial (Uji t)}

Uji statistik t (uji parsial) pada dasarnya menunjukkan seberapa jauh pengaruh satu variabel penjelas/independen secara individual dalam menerangkan variasi variabel dependen (Ghozali, 2013:98).

\section{HASIL PENELITIAN DAN PEMBAHASAN}

\section{Hasil Pengumpulan Data}

Pada penelitian faktor-faktor yang mempengaruhi minat implementasi PSAK 109 pada Organisasi Pengelola Zakat di Kota Balikpapan yang menjadi objek penelitian adalah karyawan yang bekerja di Organisasi Pengelola Zakat (OPZ) Kota Balikpapan yang terdiri atas pimpinan atau kepala cabang OPZ, bagian keuangan, bagian fundraising dan bagian penyaluran/pendayagunaan dana zakat dan infaq/sedekah.

Kuesioner disebarkan di OPZ yang sudah memberikan izin penelitian dan sudah menerapkan PSAK 109 dengan cara mengantar langsung kuesioner penelitian ke masing-masing kantor OPZ yang ada di Kota Balikpapan. Dari 34 kuesioner yang disebarkan, sebanyak 31 kuesioner kembali dan dapat diolah sebagai data

\section{Uji Validitas dan Uji Reliabilitas}




\section{Uji Validitas}

Pengujian validitas dilakukan dengan melakukan korelasi bivariate antara masingmasing skor indikator dengan total skor konstruk. Hasil analisis korelasi bivariate dengan melihat output Pearson Correlation (Ghozali,2013). Hasil uji validitas menunjukkan bahwa butir-butir pertanyaan pada variabel sikap amil, norma subjektif amil, kontrol perilaku amil, pengetahuan amil tentang PSAK 109 dan minat implementasi mempunyai output $r$ hitung lebih dari $r$ tabel $(3,009)$ sehingga dinyatakan lolos uji validitas.

\section{Uji Reliabilitas}

Pengujian ini dilakukan dengan menghitung koefisien cronbach alpha dari masing-masing instrumen dalam suatu variabel. Instrumen dapat dikatakan reliabel apabila memiliki koefisien cronbach alpha lebih dari 0,70 .

Tabel 4.6

Hasil Uji Reliabilitas

\begin{tabular}{|l|l|l|}
\hline Variabel & Cronbach'S Alpha & Keterangan \\
\hline Sikap Amil & .936 & Reliabel \\
\hline Norma Subyektif Amil & .966 & Reliabel \\
\hline Kontrol Perilaku Amil & .903 & Reliabel \\
\hline Pengetahuan Amil tentang PSAK 109 & .920 & Reliabel \\
\hline Minat Implementasi PSAK 109 & .976 & Reliabel \\
\hline
\end{tabular}

Sumber : data diolah dari SPSS 20.0, 2020

\section{Analisis Deskriptif}

Deskripsi nilai-nilai statistik dari variabel penelitian dapat dilihat pada tabel berikut:

Tabel 4.7

\section{Analisis Statistik Deskriptif}

\begin{tabular}{|c|c|c|c|c|c|c|c|}
\hline \multirow{3}{*}{ Sumbe } & \multicolumn{7}{|c|}{ Descriptive Statistics } \\
\hline & & N & Minimum & Naximum & \multicolumn{2}{|c|}{ Mean } & Sta. Deviation \\
\hline & & Statistic & Statistic & Statistic & Statistic & Std Error & Statistic \\
\hline & Sikap Amil & 31 & 101 & 139 & 114.39 & 1.895 & 10.550 \\
\hline & Norma SubyektifiAmil & 31 & 105 & 140 & 113.90 & 1.669 & 9.293 \\
\hline & Kontrol Perilaku Amil & 31 & 13 & 25 & 20.84 & .399 & 2.223 \\
\hline & $\begin{array}{l}\text { Pengetatuanan tentang } \\
\text { PSAK } 109\end{array}$ & 31 & 51 & 70 & 58.00 & .911 & 5.073 \\
\hline & $\begin{array}{l}\text { Minat Implementasi PSAK } \\
109\end{array}$ & 31 & 105 & 140 & 117.68 & 2.036 & 11.338 \\
\hline
\end{tabular}




\section{Uji Asumsi Klasik}

\section{Uji Normalitas}

Uji Normalitas adalah untuk melihat apakah nilai residual terdistribusi normal atau tidak Ada dua cara untuk mendeteksi apakah residual terdistribusi normal atau tidak, yaitu dengan analisis grafik dan uji statistik sebagai berikut :

\section{Gambar 4.1}

\section{Grafik P-Plot}

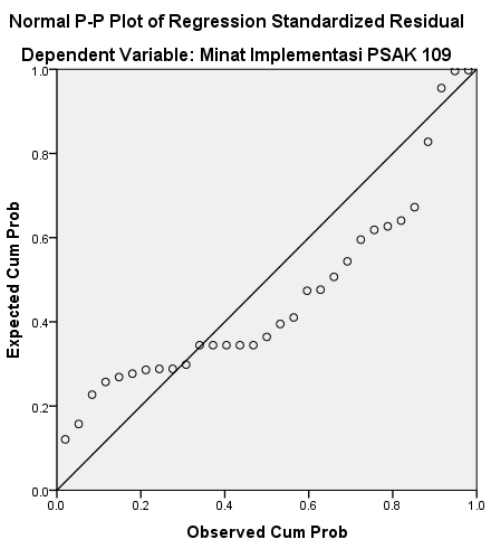

Berdasarkan tampilan grafik P-Plot di atas menunjukkan bahwa pola terdistribusi normal, sehingga memenuhi asumsi normalitas akan tetapi dalam uji normalitas dengan grafik dapat menyesatkan apabila tidak teliti karena secara visual terlihat normal. Cara berikutnya adalah menggunakan uji statistik dengan menggunakan uji statistik non parametrik Kolmogorov-Smirnov untuk lebih meyakinkan hasil yang didapatkan. Hasil uji Kolmogorov-Smirnov ditampilkan dalam tabel berikut:

Tabel 4.8

\section{Hasil Uji Grafik Kolmogorov-Smirnov}

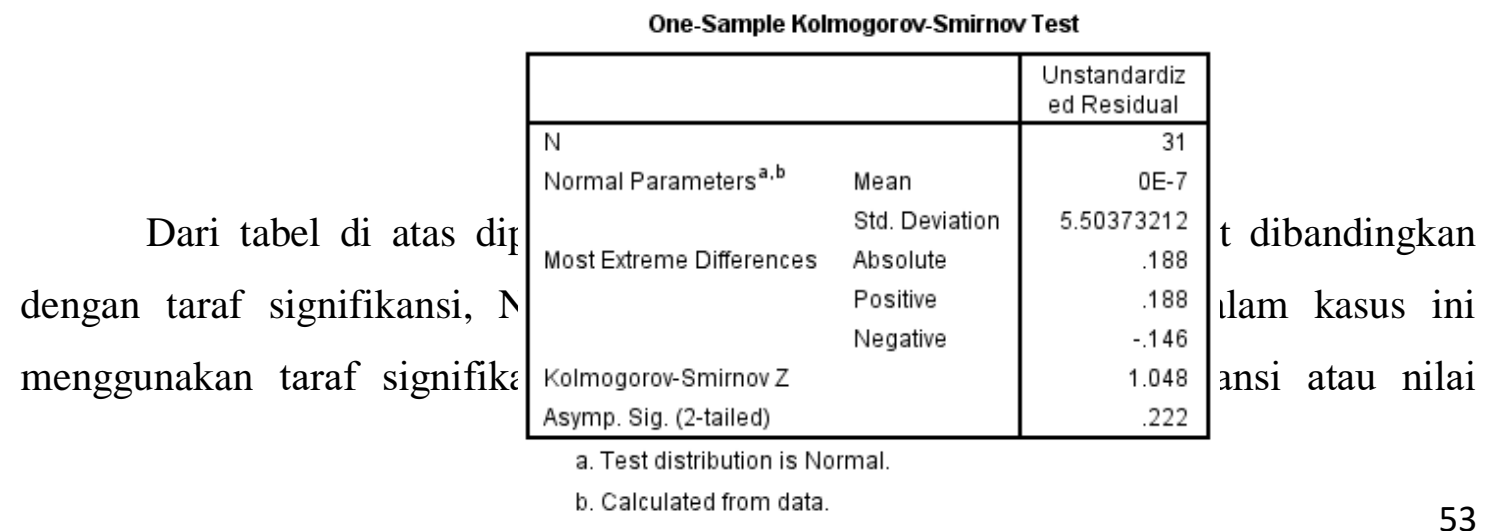


probabilitas $<0,05$, artinya adalah data residual terdistribusi tidak normal. Sedangkan jika nilai signifikansi atau nilai probabilitas > 0,05, artinya adalah data residual terdistribusi normal. Berdasarkan hasil olah data yang dapat dilihat dari tabel $4.8 \mathrm{di}$ atas bahwa nilai Asymp. Sig. (2tailed) angka probabilitas >0,05 atau 0,222 >0,05 jadi model regresi terdistribusi normal.

\section{Uji Multikolinearitas}

Uji Multikolinearitas ini bertujuan untuk mengetahui ada tidaknya variabel independen yang memiliki kemiripan antar variabel independen dalam suatu model. Kemiripan antar variabel independen akan mengakibatkan korelasi yang sangat kuat. Hasil uji multikolinearitas dapat dilihat pada gambar berikut:

\section{Gambar 4.2}

\section{Hasil Uji Multikolinieritas}

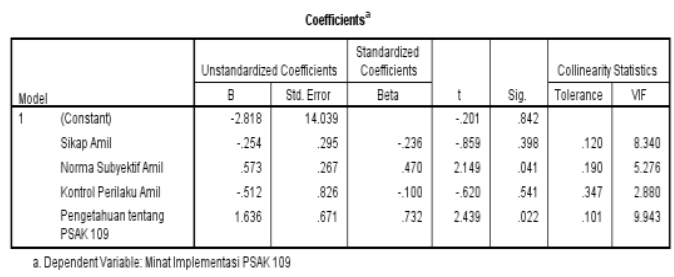

Dari hasil uji multikolinearitas pada tabel dapat dilihat bahwa semua variabel independen mempunyai nilai VIF yang kurang dari 10 dan tolerance lebih dari 0,10 . Maka dapat disimpulkan bahwa tidak ada multikolinearitas antar variabel independen dalam model regresi.

\section{Uji Heteroskedastisitas}

Ghozali (2013:139) menjelaskan uji heteroskedastisitas bertujuan menguji terjadinya perbedaan variance residual suatu periode pengamatan ke periode pengamatan yang lain. Pada penelitian ini pengujian heteroskedasitisitas dilakukan dengan metode grafik dan uji glejser dengan hasil sebagai berikut:

\section{Gambar 4.3}

\section{Hasil Uji Heteroskedastisitas dengan Metode Grafik}




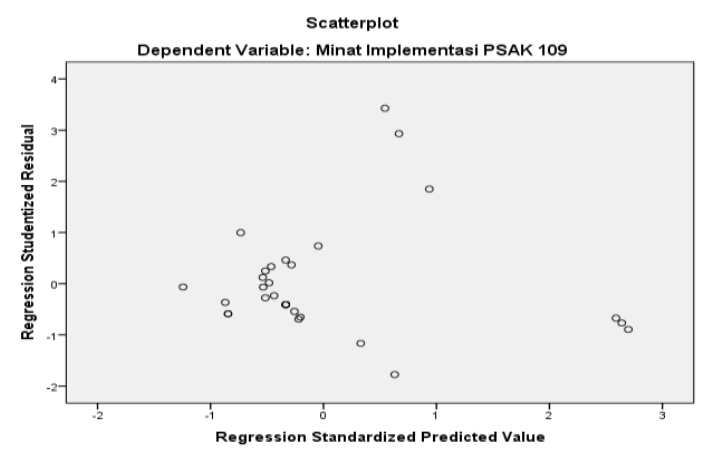

Sumber : data diolah dari SPSS 20.0, 2020

Dari gambar scatterplot diatas dapat dilihat jika tidak terjadi heteroskedastisitas sehingga memenuhi uji asumsi klasik akan tetapi dalam uji heteroskedastisitas dengan grafik dapat menyesatkan apabila tidak teliti karena secara visual terlihat normal. Cara berikutnya adalah menggunakan uji glejser untuk lebih meyakinkan hasil yang didapatkan.

Tabel 4.9

\section{Hasil Uji Glejser}

\begin{tabular}{|c|c|c|c|c|c|c|}
\hline \multicolumn{7}{|c|}{ Coefficients $^{\mathrm{a}}$} \\
\hline \multirow[b]{2}{*}{ Model } & & \multicolumn{2}{|c|}{ Unstandardized Coefficients } & \multirow{2}{*}{$\begin{array}{c}\begin{array}{c}\text { Standardized } \\
\text { Coefficients }\end{array} \\
\text { Beta } \\
\end{array}$} & \multirow[b]{2}{*}{$t$} & \multirow[b]{2}{*}{ Sig. } \\
\hline & & $B$ & Std. Error & & & \\
\hline 1 & (Constant) & -14.982 & 8.921 & & -1.679 & .105 \\
\hline & Sikap Amil & .011 & .188 & .030 & .058 & .954 \\
\hline & Norma Subyektiff Amil & .024 & .170 & .056 & .139 & .891 \\
\hline & Kontrol Perilaku Amil & .425 & .525 & .240 & .809 & .426 \\
\hline & $\begin{array}{l}\text { Pengetahuan tentang } \\
\text { PSAK } 109\end{array}$ & .239 & .426 & .309 & .560 & .580 \\
\hline
\end{tabular}

Sumber data diolah dari SPSS 20.0, 2020

Berdasarkan hasil output SPSS diatas menunjukkan bahwa nilai sig $>0,05$. Hal ini dapat disimpulkan bahwa tidak terjadi heteroskedastisitas pada model regresi, sehingga model regresi layak dipakai untuk memprediksi minat implementasi PSAK 109.

\section{Analisis Regresi Linier Berganda}

Analisis regresi ganda digunakan oleh peneliti untuk mengetahui pengaruh atau hubungan secara linier antara dua atau lebih variabel independen dengan satu variabel dependen. Dalam penelitian ini variabel dependen yaitu minat implementasi PSAK 
109, sedangkan variabel independen yaitu sikap amil, norma subjektif amil, kontrol perilaku amil dan pengetahuan amil tentang PSAK 109. Hasil analisis regresi linear berganda dengan menggunakan SPSS Versi 20.0 dapat dilihat pada tabel berikut:

Tabel 4.10

\section{Hasil Uji Regresi Berganda}

\begin{tabular}{|c|c|c|c|c|c|c|}
\hline \multicolumn{7}{|c|}{ Coefficients $^{\mathrm{a}}$} \\
\hline \multirow[b]{2}{*}{ Model } & & \multicolumn{2}{|c|}{ Unstandardized Coefficients } & \multirow{2}{*}{$\begin{array}{c}\text { Standardized } \\
\text { Coefficients }\end{array}$} & \multirow[b]{2}{*}{$t$} & \multirow[b]{2}{*}{ Sig. } \\
\hline & & B & Std. Error & & & \\
\hline 1 & (Constant) & -2.818 & 14.039 & & .201 & .842 \\
\hline & Sikap Amil & .254 & .295 & -.236 & .859 & .398 \\
\hline & Norma Subyektif Amil & .573 & .267 & .470 & 2.149 & .041 \\
\hline & Kontrol Perilaku Amil & -.512 & .826 & -100 & .620 & .541 \\
\hline & $\begin{array}{l}\text { Pengetahuan tentang } \\
\text { PSAK } 109\end{array}$ & 1.636 & .671 & .732 & 2.439 & .022 \\
\hline
\end{tabular}

Sumber : data diolah dari SPSS 20.0, 2020

Berdasarkan tabel di atas, maka persamaan regresi linear berganda pada variabel minat implementasi PSAK 109 adalah:

$$
\mathrm{Y}=-\mathbf{2 , 8 1 8}-0,254 \mathrm{X} 1+0,573 \mathrm{X} 2-0,512 \mathrm{X3}+1,636 \mathrm{X} 4+\mathrm{e}
$$

\section{Koefisien Korelasi}

Analisis korelasi ganda (R) bertujuan untuk mengukur derajat keeratan hubungan antara dua variabel. Nilai $\mathrm{R}$ terletak antara -1 dan +1 atau $-1 \leq \mathrm{R} \leq+1$.

Tabel 4.11

\section{Hasil Uji Koefisien Korelasi (R)}

Model Summary
\begin{tabular}{|l|c|r|r|r|c|}
\hline Model & \multicolumn{1}{c|}{ R } & R Square & $\begin{array}{c}\text { Adjusted R } \\
\text { Square }\end{array}$ & $\begin{array}{c}\text { Std. Error of } \\
\text { the Estimate }\end{array}$ & $\begin{array}{c}\text { Durbin- } \\
\text { Watson }\end{array}$ \\
\hline 1 & $.874^{\mathrm{a}}$ & .764 & .728 & 5.912 & 1.558 \\
\hline
\end{tabular}
a. Predictors: (Constant), Pengetahuan tentang PSAK 109, Kontrol Perilaku
Amil, Norma Subyektif Amil, Sikap Amil
b. Dependent Variable: Minat Implementasi PSAK 109

Berdasarkan tabel di atas dapat dilihat bahwa nilai $\mathrm{R}$ sebesar 0,874 dimana berdasarkan pedoman interpretasi terhadap koefisien korelasi nilai tersebut berada pada posisi $0,800-0,1000$. Hal ini menunjukkan bahwa terjadi hubungan yang sangat kuat.

\section{Koefisien Determinasi}


Koefisien Determinasi $\left(\mathrm{R}^{2}\right)$ digunakan untuk mengukur seberapa jauh kemampuan model dalam menerangkan variasi variabel independen

Tabel 4.12

\section{Hasil Uji Koefisien Determinasi $\left(\mathbf{R}^{2}\right)$}

\begin{tabular}{|c|c|c|c|c|c|}
\hline \multicolumn{6}{|c|}{ Model Summary ${ }^{b}$} \\
\hline Model & $R$ & R Square & $\begin{array}{l}\text { Adjusted R } \\
\text { Square }\end{array}$ & $\begin{array}{l}\text { Std. Error of } \\
\text { the Estimate }\end{array}$ & $\begin{array}{l}\text { Durbin- } \\
\text { Watson }\end{array}$ \\
\hline 1 & $.874^{\mathrm{d}}$ & .764 & .728 & 5.912 & 1.558 \\
\hline \multicolumn{6}{|c|}{$\begin{array}{l}\text { a. Predictors: (Constant), Pengetahuan tentang PSAK 109, Kontrol Perilaku } \\
\text { Amil, Norma SubyekdiffAmil, Sikap Amil }\end{array}$} \\
\hline b. D & ent $V_{s}$ & de: Mina & dementasi P & & \\
\hline
\end{tabular}

Dari tabel di atas dapat diketahui bahwa nilai $R$ Square $=0,764$ yang berarti pengaruh variabel independen terhadap variabel dependen sebesar 76,4\%. Hal ini menunjukkan bahwa kontribusi dari variasi keempat variabel independen yang digunakan sedangkan sisa 23,6 \% dipengaruhi atau dijelaskan oleh variabel lain yang tidak dimasukkan dalam penelitian ini.

\section{Uji Signifikansi Simultan (Uji F)}

Uji $\mathrm{F}$ dilakukan untuk mengetahui besarnya dampak atau pengaruh secara nyata antar variabel independen terhadap variabel dependen dan untuk menguji pengaruh variabel bebas secara simultan atau Bersama-sama terhadap variabel terikat. Hasil uji signifikansi simultan

pada penelitian ini disajikan pada tabel 4.13 sebagai berikut:

Tabel 4.13

\section{Hasil Uji Signifikansi F}

\begin{tabular}{|c|c|c|c|c|c|c|}
\hline \multicolumn{7}{|c|}{ ANOVA ${ }^{a}$} \\
\hline Model & & $\begin{array}{l}\text { Sum of } \\
\text { Squares }\end{array}$ & df & Mean Square & $\mathrm{F}$ & Sig. \\
\hline \multirow{3}{*}{1} & Regression & 2948.042 & 4 & 737.011 & 21.087 & $.000^{b}$ \\
\hline & Residual & 908.732 & 26 & 34.951 & & \\
\hline & Total & 3856.774 & 30 & & & \\
\hline
\end{tabular}

Berdasarkan kriteria pengujian dapat disimpulkan bahwa $F_{h i t u n g}>F_{\text {tabel }}$ atau 21,087 $>$ 2,74 maka $\mathrm{H}_{0}$ ditolak. Jika dilihat dari signifikansinya maka $\mathrm{H}_{0}$ ditolak. Hal ini disebabkan karena nilai signifikansi nya $0,00<0,05$. Dengan demikian dapat 
dikatakan bahwa variabel sikap amil, norma subyektif amil, kontrol perilaku amil dan pengetahuan amil tentang PSAK 109 secara bersama-sama atau simultan berpengaruh positif terhadap minat implementasi PSAK 109.

\section{Uji Signifikan / Uji t ( $t$ test)}

Uji t digunakan untuk menguji seberapa jauh pengaruh satu variabel penjelas atau independen secara individual menerangkan variansi variabel dependen secara parsial. Pengambilan keputusan dilakukan dengan melihat nilai signifikansi di tabel koefisien atau berdasarkan perbandingan nilai $t_{\text {hitung masing-masing koefisien }}$ regresi dengan $t_{\text {tabel }}$ sesuai dengan tingkat signifikansi yang digunakan.

Hasil uji signifikansi parsial pada penelitian ini disajikan pada tabel 4.14 sebagai berikut:

\section{Tabel 4.14}

\section{Hasil Uji t}

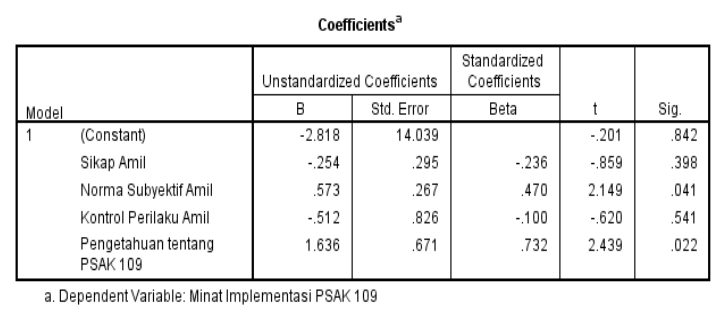

Berdasarkan kriteria pengujian di atas dapat diketahui bahwa

1. $\mathrm{t}_{\text {hitung }}<\mathrm{t}$ tabel atau $-0,8591<1,70562$ sehingga $\mathrm{H}_{0}$ diterima. Jika dilihat dari signifikansinya maka $\mathrm{H}_{0}$ diterima. Dengan demikian dapat disimpulkan bahwa sikap amil tidak berpengaruh positif terhadap minat implementasi PSAK 109.

2. $\mathrm{t}$ hitung $>\mathrm{t}$ tabel atau 2,149>1,70562 sehingga $\mathrm{H} 0$ ditolak. Jika dilihat dari signifikansinya maka H0 ditolak. Dengan demikian dapat disimpulkan bahwa norma subjektif amil berpengaruh positif terhadap minat implementasi PSAK 109.

3. $\mathrm{t}$ hitung $<\mathrm{t}$ tabel atau $-0,620<1,70562$ sehingga H0 diterima. Dengan demikian dapat disimpulkan bahwa kontrol perilaku amil tidak berpengaruh positif terhadap minat implementasi PSAK 109. 
4. $\mathrm{t}$ hitung $>\mathrm{t}$ tabel atau 2,439 > 1,70562 sehingga H0 ditolak. Dengan demikian dapat disimpulkan bahwa pengetahuan tentang PSAK 109 berpengaruh positif terhadap minat implementasi PSAK 109.

\section{Pembahasan Hasil Penelitian}

A. Pengaruh sikap terhadap minat

Hipotesis pertama $\left(\mathrm{H}_{1}\right)$ yang menyatakan bahwa sikap amil berpengaruh positif terhadap minat implementasi akuntansi zakat PSAK No. 109 ditolak. Hal tersebut sesuai dengan hasil penelitian dari Pujianto (2015) serta Amanda dan Mi Mitha (2017) yang menyatakan bahwa sikap tidak berpengaruh secara positif signifikan terhadap minat.

Variabel sikap tidak berpengaruh positif pada penelitian ini disebabkan karena keyakinan amil terkait keuntungan atau manfaat dari mengimplementasikan PSAK No. 109. Jika amil merasa implementasi PSAK No. 109 ini tidak memberikan pengaruh yang signifikan terhadap perkembangan organisasi pengelola zakat dan cenderung menghabiskan banyak waktu juga biaya dalam penerapannya maka sikap amil cenderung tidak memiliki minat untuk implementasi PSAK No. 109

B. Pengaruh norma subyektif terhadap minat

Hipotesis kedua $\left(\mathrm{H}_{2}\right)$ yang menyatakan bahwa norma subyektif amil berpengaruh positif terhadap minat implementasi akuntansi zakat PSAK No. 109 diterima. Hal tersebut sesuai dengan hasil penelitian dari Pujianto (2015) dan Rachmantika (2018) yang menyatakan bahwa norma subyektif memiliki pengaruh positif signifikan terhadap minatimplementasi PSAK No. 109. Norma subyektif adalah tekanan sosial yang dirasakan seseorang untuk melakukan atau tidak melakukan sesuatu. Dalam hal ini pihak-pihak yang berkepentingan memiliki pengaruh untuk menekan amil OPZ mengimplementasikan PSAK No. 109 dalam proses akuntansi dan pelaporan keuangannya. Semakin tinggi norma subjektif yang diterima amil maka akan semakin meningkatkan minat implementasi PSAK No. 109 pada organisasi pengelola zakat di Kota Balikapan. 
C. Pengaruh kontrol perilaku terhadap minat

Hipotesis ketiga $\left(\mathrm{H}_{3}\right)$ yang menyatakan bahwa kontrol perilaku amil berpengaruh positif terhadap minat implementasi akuntansi zakat PSAK No. 109 ditolak. Hal tersebut sesuai dengan hasil penelitian dari Wibowo (2016) yang menyatakan jika kontrol perilaku tidak berpengaruh positif signifikan terhadap minat.

Pada penelitian ini variabel kontrol perilaku tidak berpengaruh positif disebabkan karena adanya faktor yang menghambat ataupun kesulitan yang dihadapi sehingga secara pribadi minat amil untuk implementasi PSAK No. 109 cenderung rendah. Faktor penghambat atau kesulitan ini bisa berasal dari berbagai hal misalnya keterbatasan sumber daya manusia yang memiliki pemahaman terkait PSAK No. 109 atau kurangnya sosialisasi tentang PSAK No. 109.

D. Pengaruh pengetahuan terhadap minat

Hipotesis keempat $(\mathrm{H} 4)$ yang menyatakan bahwa pengetahuan tentang PSAK No. 109 berpengaruh positif terhadap minat implementasi akuntansi zakat PSAK No. 109 diterima. Hal tersebut sesuai dengan hasil penelitian dari Sugiarto (2018) dan Lohanda (2017) yang menyatakan jika pengetahuan berpengaruh positif signifikan terhadap minat.

Hasil olah data menunjukkan jika pengetahuan tentang PSAK 109 memiliki pengaruh positif signifikan dengan tingkat tertinggi dibandingkan variabel independen lainnya dalam mempengaruhi minat implementasi PSAK No. 109. Sehingga dapat ditarik kesimpulan jika amil memiliki pengetahuan dan pemahaman tentang PSAK No. 109 maka minat untuk menerapkan PSAK No. 109 dalam penyusunan laporan keuangan organisasi pengelola zakat cenderung tinggi.

\section{PENUTUP}

\section{Kesimpulan}

Penelitian ini bertujuan untuk meneliti pengaruh dari sikap, norma subjektif, kontrol perilaku dan pengetahuan tentang PSAK No. 109 terhadap minat implementasi 
PSAK No. 109 pada Organisasi Pengelola Zakat yang ada di Kota Balikpapan. Berdasarkan hasil penelitian dan pembahasan, maka diambil kesimpulan sebagai berikut

1. Sikap amil tidak berpengaruh positif signifikan terhadap minat implementasi PSAK No. 109 pada Organisasi Pengelola Zakat di Kota Balikpapan

2. Norma subjektif amil berpengaruh positif signifikan terhadap minat implementasi PSAK No. 109 pada Organisasi Pengelola Zakat di Kota Balikpapan.

3. Kontrol perilaku amil tidak berpengaruh positif signifikan terhadap minat implementasi PSAK No. 109 pada Organisasi Pengelola Zakat di Kota Balikpapan.

4. Pengetahuan tentang PSAK No. 109 berpengaruh positif signifikan terhadap minat implementasi PSAK No. 109 pada Organisasi Pengelola Zakat di Kota Balikpapan.

\section{Saran}

Saran-saran yang dapat penulis kemukakan dalam penelitian ini adalah sebagai berikut

1.Peneliti menyarankan akademisi yang akan melakukan penelitian terkait tentang akuntansi zakat atau minat perilaku agar mencari literatur yang lebih lengkap tentang akuntansi syariah berkaitan dengan zakat dan infaq/sedekah serta akuntansi keperilakuan agar penelitian selanjutnya lebih memahami tentang faktor-faktor lain yang dapat mempengaruhi minat perilaku selain yang dikemukakan oleh peneliti.

2. Teknik pengambilan sampel penelitian ini hanya menggunakan instrumen berupa kuesioner yang dibagikan kepada responden. Untuk penelitian selanjutnya disarankan untuk melakukan penelitian dengan metode yang berbeda seperti menggunakan metode penelitian kualitatif dan teknik pengumpulan data berupa wawancara dan dokumentasi agar mendapatkan informasi yang lebih akurat dan terhindar dari timbulnya perbedaan interpretasi.

3. Bagi IAI pusat dan IAI perwakilan cabang wilayah Balikpapan selain mengadakan kegiatan sosialisasi secara langsung berkaitan dengan PSAK No. 109 juga dapat memanfaatkan perkembangan teknologi informasi komunikasi melalui akun media sosial, website ataupun channel youtube milik IAI untuk memberikan edukasi dan pemahaman akan pentingnya implementasi akuntansi zakat PSAK No. 109 kepada 
OPZ sekaligus memudahkan masyarakat umum untuk lebih mengetahui fungsi dan peran akuntansi zakat PSAK No. 109.

4. Bagi Organisasi Pengelola Zakat yang belum menerapkan PSAK No. 109 disarankan untuk mengadakan pelatihan dan pendidikan bagi amil supaya dapat meningkatkan kualitas sumber daya manusia sehingga dapat mendukung terbentuknya laporan keuangan yang sesuai standar dan berkualitas.

\section{DAFTAR PUSTAKA}

Amanda, Kurnia dan Mi Mitha. 2017. Faktor-Faktor yang Mempengaruhi Minat Penggunaan Sistem Informasi Terkomputerisasi pada UKM (Pendekatan Theory of Planned Behavior). Jurnal Akuntansi 9(1) : 23-33

Angraeni, Elvinda Febry, dkk. 2016. Penerapan Akuntansi Zakat dan Infak/Sedekah Berdasarkan PSAK 109 Pada Badan Amil Zakat Kota Bitung. Jurnal EMBA 4(4): 1191-1199.

Anonim. Kata Kunci “Pengelolaan Zakat”. www.zentadacon.wordpress.com diakses pada tanggal 20 Desember 2019.

Apriliani, Eka. 2017. Pengaruh Kompetensi Sumber Daya Manusia, Penerapan Standar Akuntansi Zakat dan Infak/Sedekah (PSAK 109), Pengendalian Intern, Pemanfaatan Teknologi Informasi, dan Employee Engagement Terhadap Kualitas Laporan Lembaga Amil Zakat di Kota Semarang. Skripsi. Universitas Negeri Semarang (UNNES). Semarang. (http://lib.unnes.ac.id/29933/1/7211413154.pdf). Diakses pada tangga 18 Desember 2019. Pukul 22.17.

Departemen Agama RI. 2006. Al-Qur'an dan Terjemahnya. Edisi Revisi. CV. Pustaka Agung Harapan. Surabaya.

Ghozali, Imam. 2013. Aplikasi Analisis Multivariate Dengan Program IBM SPSS 21 Update PLS Regresi. Edisi Tujuh. Cetakan Ketujuh. Badan Penerbit Universitas Diponegoro. Semarang.

Hatta, Madani, dkk. 2017. Perilaku Berbagi Pengetahuan Akuntansi Pada Dosen Akuntansi Kota Bengkulu : Pendekatan Theory of Planned Behavior (TPB). Jurnal Akuntansi, Ekonomi dan Manajemen Bisnis 5(1): 26-44.

Ikatan Akuntansi Indonesia. 2008. Exposure Draft Pernyataan Standar Akuntansi Keuangan Akuntansi Zakat dan Infak/Sedekah. Jakarta: Dewan Standar Akuntansi Keuangan Ikatan Akuntan Indonesia. 
Lohanda, Dedi. 2017. Pengaruh Tingkat Pendidikan, Pemahaman Akuntansi, dan Pelatihan Penyusunan Laporan Keuangan Terhadap Pelaporan Keuangan UMKM Berdasarkan SAK ETAP (Studi Kasus pada UMKM Kerajinan Batik di Kecamatan Kraton Yogyakarta). Skripsi. Universitas Negeri Yogyakarta (UNY).Yogyakarta.(http://eprints.uny.ac.id/57297/1/Pengaruh\%20Tingkat\%20Pendidi kan\%2C\%20Pemahaman\%20Akuntansi\%2C\%20Pelatihan\%20Penyusunan\%20Lapor an\%20Keuangan\%20Terhadap\%20.pdf). Diakses pada tanggal 18 Desember 2019. Pukul 22.45.

Ma'sumah, Ngalimatul, dan Amin Pujiati. 2018. Pengaruh Sikap, Norma Subyektif, dan Kontrol Perilaku Persepsian Terhadap Niat Berwirausaha Siswa. Economic Education Analysis Journal 7(1): 194-206.

Megawati, Devi, dan Fenny Trisnawati. 2014. Penerapan PSAK 109 Tentang Akuntansi Zakat dan Infak/Sedekah Pada BAZ Kota Pekanbaru. Jurnal Penelitian Sosial Keagamaan 17(1): 40-50.

Nurhayati, Sri dan Wasilah. 2013. Akuntansi Syariah di Indonesia. Edisi Ketiga. Salemba Empat. Jakarta.

Pandapotan, Ritonga. 2017. Analisis Akuntansi Zakat Berdasarkan PSAK No. 109 Pada Badan Amil Zakat Nasional (BAZNAS) Sumatera Utara. Kitabah 1(1): 11-18.

Pertiwi, Anggun Rita et al., 2015. Analisis Penerapan Akuntansi Dana Zakat Dan Infak/Sedekah Pada Lembaga Amil Zakat Infak, Dan Shodaqoh Muhammadiyah (LAZISMU) Kabupaten Malang. JRAK 5(2): 751-758

Pratiwi, Rima Harpina. 2017. Pengujian Theory of Planned Behavior dan Motivasi Terhadap Minat Mahasiswa Akuntansi Memperoleh Sertifikasi Chartered Accountant (CA) (Studi Kasus pada Mahasiswa Akuntansi Syariah IAIN Surakarta). Skripsi. Institut Agama Islam Negeri Surakarta (IAIN Surakarta).Surakarta.(http://eprints.iainsurakarta.ac.id/865/1/skripsi\%20rima\%20harpin a\%20pratiwi\%20132221042.pdf). Diakses pada tanggal 24 Desember 2019. Pukul 22.10 .

Priyatno, Duwi. Belajar Cepat Olah Data Statistik dengan SPSS. 2012. Andi. Yogyakarta.

Pujianto. 2015. Implementasi PSAK 109 Tentang Akuntansi Zakat dan Infak/Sedekah (Studi Empiris pada Organisasi Pengelola Zakat dan Infak/Sedekah Di Kota Semarang). Skripsi. Universitas Negeri Semarang (UNNES).Semarang.(http://lib.unnes.ac.id/22566/1/7211410096-s.pdf). Diakses pada tanggal 28 Oktober 2019. Pukul 21.15.

Rachmantika, Cahya Tri. 2018. SIKAP, NORMA SUBJEKTIF, DAN KONTROL PERILAKU TERHADAP MINAT BELI KOSMETIK HALAL. Skripsi. Universitas 
Islam Negeri Surakarta. Surakarta. (http://eprints.iainsurakarta.ac.id/2259/1/Cahya\%20Tri\%20R.pdf). Diakses pada tanggal 29 Juni 2020. Pukul 20.14

Samryn, L.M. Pengantar Akuntansi. 2011. PT Rajagrafindo Persada. Jakarta.

Sari, Ratna Candra. 2018. Akuntansi Keperilakuan. Andi. Yogyakarta.

Setyani, Ayu Dian. 2018. PENERAPAN PSAK NO. 109 PADA PENYUSUNAN LAPORAN KEUANGAN DI BADAN AMIL ZAKAT NASIONAL (BAZNAS) KABUPATEN GRESIK PERIODE JANUARI-DESEMBER 2017. Surabaya. Skripsi. Universitas Islam Negeri Sunan Ampel Surabaya. (http://digilib.uinsby.ac.id/26419/1/Ayu\%20Dian\%20Setyani G72214020.pdf). Diakses pada tanggal 29 Juni. Pukul 02.30

Shahnaz, Sabrina. 2015. Penerapan PSAK No. 109 Tentang Pelaporan Keuangan Akuntansi Zakat, Infaq/Sedekah Pada Badan Amil Zakat Provinsi Sulawesi Utara. Jurnal Emba 3(4): 318-323.

Suartana, I Wayan. 2010. Akuntansi Keperilakuan : Teori dan Implementasi. Andi. Yogyakarta.

Sugiarto, Aji. 2018. Pengaruh Pengetahuan, Persepsi, Sikap, Dan Perilaku Pelaku Bisnis Terhadap Minat Bertransaksi Di Perbankan Syariah. Yogyakarta. Skripsi. Universitas Islam Negeri Sunan Kalijaga. (http://digilib.uin-suka.ac.id/31630/2/13820175 BAB-I IVatau-V DAFTAR-PUSTAKA.pdf).Diakses pada tanggal 29 Juni. Pukul 19.42

Sugiyono. 2016. Metode Penelitian Kuantitatif, Kualitatif, dan R\&D. 2016. Cetakan Kedua Puluh Tiga. Alfabeta. Bandung.

Suryani, Hendrayadi. 2015. Metode Riset Kuantitatif Bidang Manajemen dan Ekonomi Islam. Cetakan Pertama. Prenadamedia Group. Jakarta

Umah, Umi Khoirul, dan Ari Kristin. 2011. Penerapan Akuntansi Zakat Pada Lembaga Amil Zakat (Studi Pada LAZ DPU DT Cabang Semarang). Value Added 7(2): 68-95.

Undang-Undang Nomor 23 Tahun 2011 tentang Pengelolaan Zakat. 25 November 2011. Lembaran Negara Republik Indonesia Tahun 2011 Nomor 115, Tambahan Lembaran Nomor 5255. Jakarta.

Undang-Undang Nomor 38 Tahun 1999 tentang Pengelolaan Zakat. 23 September 1999. Lembaran Negara Republik Indonesia Tahun 1999 Nomor 164, Tambahan Lembaran Nomor 3885. Jakarta.

Wibosono, Yusuf. 2015. Mengelola Zakat Indonesia. Edisi Pertama. Cetakan Pertama. Prenadamedia Group. Jakarta. 
Wibowo, Amanda Anidia Ita. 2016. Analisis Pengaruh Sikap, Norma Subyektif, Dan Kontrol Perilaku Yang Dirasakan Terhadap Minat Beli Produk Private Brand Alfamart Di Sekitar Universitas Muhammadiyah Surakarta.

Yasin, Ahmad Hadi. 2011. Panduan Zakat Praktis. www.zakat.or.id diakses pada tanggal 31 Desember 2019. Pukul 20.15.

(https://baznas.go.id/id/sedekah) diakses pada tanggal 13 Desember 2019. Pukul 22.15.

https://syaharuddinalmusthafa.blogspot.com/2013/04/pengertian-nilai-alfha-dalamstatistika.html. 

